Драгана Радојчић

Универзитет у Београду

Филолошки факултет

Катедра за славистику

draganaradojcic16@gmail.com
УДК 811.161.1 Кошутић, Р. https://doi.org/10.18485/slavistika.2019.23.2.14

Прегледни рад примљено 18.03.2019. прихваћено за штампу 10.10.2019.

\title{
РУСИСТИЧКО НАСЛЕЪЕ РАДОВАНА КОШУТИЋА У НАУЧНОЈ КРИТИЦИ
}

У раду се говори о доприносу Радована Кошутића на пољу славистике и лингвистичке русистике, пре свега кроз преглед радова писаних о њему, односно тумачење Кошутићевог доприноса од стране његових савременика и послератних русиста у Југославији и Србији.

Кључне речи: Радован Кошутић, граматика, диференцијални метод, методологија проучавања инословенског језика, лингводидактика, конфронтациона проучавања.

The paper discusses the contribution of Radovan Košutić in the field of Slavic studies and the linguistic study of the Russian language, primarily through the review of papers written about him as well as through the interpretation of Košutić's contribution provided by his contemporaries and post-war Yugoslav and Serbian Russianists.

Keywords: Radovan Košutić, grammar, differential method, methodology of other Slavic language study, lingo-didactic, contrastive linguistic studies.

Дело Радована Кошутића оставило је неизбрисив траг у српској русистици. Кошутић се и данас с правом сматра утемељивачем нових метода учења руског језика у блискосродној словенској средини. Његов диференцијални метод који се заснива на систематичној анализи и поређењу елемената руског и српског језика сматра се претечом контрастивне анализе, као новог приступа у лингвистици. Многе русисте инспирисао је за даља истраживања у области лингводидактике и лингвокултурологије.

Рођен је 20. фебруара 1866. године у Руми. Школовао се у Сремским Карловцима и Новом Саду, где је 1885. завршио гимназију. Исте године почиње студије словенских језика и књижевности у Бечу. Наставља их у Прагу, затим у Кракову, Лавову, Санкт Петербургу. Дипломирао је у Бечу 1890. За доктора филозофије honoris causa на Јагјелоњском универзитету у Кракову био је изабран 1900. До 1905. био је предавач („привремени учитељ“) за руски, чешки и пољски језик и књижевност на Великој школи. Стални доцент Београдског универзитета за језике и књижевности Источних и Западних Словена постао је 1905. Редовни професор постаје 1922. За дописног члана Академије наука СССР изабран је 1928. године, а 1929. за дописног члана Словенског института у Прагу. Пензионисан је 1936. Умро је 9. априла 1949. у Опову, а његов гроб налази се данас на београдском Новом гробљу (Пипер 2016: 286-287).

Кошутић је у свом научном и наставном раду имао многе тешкоће. Током Октобарске револуције, у Петрограду му је пропао рукопис скоро завршеног руско-српског речника. За велики српско-руски речник није имао новца, нити разумевања од стране београдског Филозофског факултета (Кончаревић 2010: 
323-324). За скраћено издање Фонетике са кратким историјским коментаром није имао издавача. Своју последњу монографију О тонској метрици у новијој српској поезији штампао је личним средствима. Политички ставови краљевине Југославије према СССР-у и Русији између два рата негативно су утицали и на наставу руског језика, тако да је Кошутић предавао само на почетним курсевима руског језика на Универзитету. Није имао ни могућности за одлазак у СССР ради синтаксичких истраживања, чиме би заокружио своју Граматику (Граматика руског језика II. Облици). У међуратном периоду дипломирало је само шест студената русистике (Кончаревић 2010: 323).

Независно од проблема са којима се борио, Кошутић је оставио богато славистичко наслеђе као непрестану инспирацију за даља проучавања. У овом раду задржаћемо се на чланцима о Радовану Кошутићу као русисти. Покушаћемо да прикажемо део доступне литературе која се бави делом Радована Кошутића.

Према неким подацима, од 1945. до 2000. у домаћим и страним публикацијама објављено је 20 чланака југословенских русиста о Радовану Кошутићу. Од 2000. до 2010. објављено је 8 прилога (Кончаревић 2010: 323-355). Б. Терзић наводи преко 60 домаћих и иностраних радова о Кошутићу (Терзић 2006: 25).

Међу првима је о Кошутићу писао његов ученик Кирил Тарановски. У некрологу поводом Кошутићеве смрти Тарановски наглашава да је Граматика руског језика II Облици произашла из темељитог проучавања руског језика, што је плод „самосталног испитивања разговорног језика руске интелигенције“ (Тарановски 1949-1950: 512-517).

Даље студије о делу Радована Кошутића објављене су 1966. у „Живим језицима“. Аутор једне био је Радован Лалић, а друге Наталија Радошевић. Лалић подржава Кошутићев диференцијални метод и истиче његову применљивост на друге језике, док је у односу на српски језик специфичан, јер га је Кошутић формулисао проучавајући диференцијалне црте српског и руског језика (Лалић 1966: 1).

Наталија Радошевић у раду Радован Кошутић и нека савремена лингвистичка схватаға наводи да је основу за свој метод могао наћи у граматици Петра Будманија из 1884. године (Praktična gramatika ruskoga jezika za samouke) и код Павла Мајзнера (1904) (Радошевић 1966: 12). У раду из 1977. Место Кошутићеве школе у развоју српске славистике, поводом стогодишњице постојања београдске Катедре за славистику, Н. Радошевић истиче значај Кошутићевог научног и дидактичког рада за каснији развој српске и светске русистике (Зборник реферата објављен је 30 година касније, у књизи Сто година славистике у Србији, 27 година после смрти Наталије Радошевић). Међутим, ауторка сматра да се Кошутић могао више посветити развијању говорних навика код ученика, мада је он то објашњавао опрезом због могуће „контаминације и руског и матерњег језика због њиховог мешања“ (Радошевић 2007: 61). На тврдње Б. Терзића и Б. Станковића да Кошутић недовољно обраћа пажњу на сличности између два језичка система, Н. Радошевић одговара да је Кошутић ипак указивао на сличности, али је сматрао да се на њима не треба задржавати, јер оне природно помажу у учењу (Радошевић 2007: 63).

Богдан Терзић у чланку из 1972. подсећа да се Кошутић као лингвиста развио из младограматичарске школе, а у раду из 1973. развија анализу Кошутићевог 
диференцијалног приступа, који обухвата међујезичку интерференцију на фонетском, фонолошком, прозодијском, ортографском, морфолошком и синтаксичком нивоу, уз лингвокултуролошке примере. У чланку Савременици о Кошутићу као русисти из 1986. године Б. Терзић пише о тумачењу Кошутићевог дела од стране његових савременика (касније је овај рад укључен у монографију Руско-српске језичке паралеле из 1999). Терзић наводи Кошутићева писма А. А. Шахматову, где изражава бојазан да Руски примери „неће наићи на признање научне критике“, јер се баве савременим текстовима, што је била новина (Терзић 1986: 21). Академик Ф. Ј. Корш пише да Кошутић као странац који изузетно добро познаје руски језик може боље од изворног говорника запазити неке танчине. Кошутићеву Граматику (Облици) приказала су три велика стручњака: Н. К. Куљман, М. Решетар и С. П. Обнорски. Куљман запажа да се у Облицима може наћи корисни материјал не само за Србе који уче руски језик, већ и за „наставника руске средње школе“. М. Решетар веома позитивно оцењује Кошутићеве Облике, мада му замера класификацију глагола на врсте према презентској основи (Лескинова подела), јер је он давао предност Миклошићевој подели по инфинитивној основи. Обнорски је написао најдетаљнији приказ Облика, уз примедбу да се Кошутић одлучио за московски књижевни изговор.

Анализом лингвокултуролошких примера код Кошутића бавили су се Богољуб Станковић и Т. Н. Черњавска (Т. Н. Чернявская) у раду Из истории лингвострановедческого подхода к преподаванию русского языка, објављеном 1978. Аутори истичу јасан лингвокултуролошки приступ у напоменама о историјским чињеницама о Русији и коментарима књижевних текстова, иако га Кошутић није могао теоријски засновати, јер се тада о овој области није ни писало. Касније је Б. Станковић у раду Основна Кошутићева полазишта у области методике наставе инословенских језика у српској средини посматрао Кошутића у контексту модерније лингводидактике, анализирајући све уџбенике које је Р. Кошутић написао.

М. Стојнић анализира лингвистичке, књижевне и културолошке критеријуме одабира књижевних текстова у Кошутићевим Примерима књижевнога језика руског. Међу лингвистичким критеријумима истиче се богатство стилова у текстовима. У књижевним критеријумима истиче се избор текстова према дидактичкој намени, а не по књижевним критикама или популарности код читалаца. (Стојнић 1986: 74). Кошутићеви лингвокултуролошки коментари чине скоро трећину друге књиге Руских примера (76 од 225 страница), иако им он није посвећивао намерну пажњу. Мила Стојнић закључује да оваква књига није само уџбеник, већ и „књига за цео живот“.

Вера Николић у раду Радован Кошутић као коментатор руских текстова (,Напомене“ - друга књига „Руских примера“) види ову књигу као „тротомну целину која представља веома скрупулозан рад на савременом тексту“ (Николић 1986: 77). Она издваја три типа објашњења у Напоменама: културолошки, лингвокултуролошки и лингвостилистички. И поред неких замерки, ауторка закључује да три књиге Руских примера и даље представљају образац за начин обраде текста (Николић 1986: 82-83).

Р. Маројевић даје преглед радова значајних слависта после Кошутића, почев од његовог ученика Кирила Тарановског. Такође констатује да су Кошутићевим 
Речником „ударени темељи двојезичне руско-српскохрватске лексикографије, која у погледу солидности лексичко-семантичке обраде није ни до данас превазиђена.“ (Маројевић 1986: 32).

О Кошутићевом лексикографском раду писао је и Љ. Милинковић, истичући да је и у овој области доследно применио свој диференцијални принцип, чиме је утемељио конфронтативну лексикологију руског и српског (српскохрватског) језика и „оставио у наслеђе образац како треба презентирати лексичку грађу генетски сродног језика.“ (Милинковић 1986: 90).

Дара Дамљановић у својој књизи Руски језик у Србији. Уибеници до 1941. године посебно издваја значај Радована Кошутића и његове Граматике руског језика. II. Облици. Д. Дамљановић је свакако дала једну од најдетаљнијих анализа овог Кошутићевог дела, као и неких детаља из архивске грађе о њему (Дамљановић 2000: 237-248).

Ксенија Кончаревић у својим монографијама поклања значајну пажњу Р. Кошутићу, а у радовима: Непознати документи о универзитетској делатности Радована Кошутића (2008), Рецепцуија дела Радована Кошутића у послератној русистичкој лингводидактиции код Срба: о шездесетогодишњици смрти (2010) и у чланку из 2016. Рецепциија дела Радована Кошутића у новијој русистичкој лингводидактиции (о стопедесетогодишюици рођеґа) опширно говори о лингводидактичком наслеђу Р. Кошутића и његовој прихваћености у српској русистици после Другог светског рата. Радови садрже детаљан преглед чланака о Кошутићу, објављених код нас. Ауторка закључује да је Кошутић оставио дубоки траг у српској послератној русистици, што чини основу за даљи развој ове области (Кончаревић 2010).

О елементима творбе речи код Кошутића писао је Д. Чампар, Кошутићевом граматичком терминологијом бавио се Б. Дабић, о Кошутићевом доприносу развоју московске фонолошке школе писала је Вера Борисенко-Свинарски, што је само део радова о овом великом филологу.

На крају, навешћемо речи Предрага Пипера о Радовану Кошутићу као утемељивачу српске филолошке русистике и његовом диференцијалном методу којим је „увео у лингвистичку методологију нови приступ описима језика, који је неколико деценија касније у америчкој лингвистици, независно од Кошутићевог дела, назван контрастивна анализа, односно контрастивна лингвистика“ (Пипер 2016: 287). На овај начин истиче се изузетан значај Кошутића не само за српску, већ и за светску лингвистику.

Овај кратки осврт на тумачење Кошутићевог дела од стране његових савременика и следбеника наводи на закључак да је његово наслеђе дало снажни подстрек српској послератној русистици и поставило темеље за даља теоријска проучавања. 


\section{Цитирана литература}

Дамљановић, Дара. Руски језик у Србији. Уџбеници до 1941. године. Београд: Филозофски факултет, 2000.

Кончаревић, Ксенија. „Непознати документи о универзитетској делатности Радована Кошутића“. Славистика ХІІ, 2008: 389-402.

Кончаревић, Ксенија. „Рецепција дела Радована Кошутића у послератној русистичкој лингводидактици код Срба“. Славистика XIV, 2010: 323-335.

Лалић, Радован. „О Кошутићевом методу учења руског језика код нас“. Живи језици 1-4, 1966: 1-10.

Маројевић, Радмило. (ур.) Славистички зборник 1: Радован Кошутић и развој југословенске славистике. Београд: Савез славистичких друштава СР Србије, 1986.

Маројевић, Радмило. „Радован Кошутић и развој југословенске лингвистичке русистике“. [У:] Р. Маројевић (ур.) Славистички зборник 1: Радован Кошутић и развој југословенске славистике. Београд: Савез славистичких друштава СР Србије, 1986, 31-46.

Милинковић, Љубо. „Лексикографски рад Радована Кошутића и савремени рускосрпскохрватски школски речници“. [У:] Р. Маројевић (ур.) Славистички зборник 1: Радован Кошутић и развој југословенске славистике. Београд: Савез славистичких друштава СР Србије, 1986, 85-91.

Николић, Вера. „Радован Кошутић као коментатор руских текстова („Напомене“ друга књига „Руских примера“)“. [У:] Р. Маројевић (ур.) Славистички зборник 1: Радован Кошутић и развој југословенске славистике. Београд: Савез славистичких друштава СР Србије, 1986, 77-84.

Пипер, Предраг. „Радован Кошутић - утемељивач српске филолошке русистике“. [У:] Базилевски Андреј (ур.) Српско-руски круг: књижевно-уметнички алманах. Москва: Вахазар; Београд: Интерпрес, 286-289.

Радошевић, Наталија. „Радован Кошутић и нека савремена лингвистичка схватања“. Живи језици 1-4, 1966: 10-14.

Станковић, Богољуб. „Основна Кошутићева полазишта у области методике наставе инословенских језика у српској средини“. [У:] Г. Јовановић (ур.) Сто година полонистике у Србији. Београд: Славистичко друштво Србије, 1996, 39-43.

Стојнић, Мила. „Критеријуми за одабир и тумачење књижевних текстова у Кошутићевим Примерима“. [У:] Р. Маројевић (ур.) Славистички зборник 1: Радован Кошутић и развој југословенске славистике. Београд: Савез славистичких друштава СР Србије, 1986, 69-75.

Тарановски, Кирил. „Радован Кошутић (1866-1949)“. Јужнословенски филолог, 1949: 512-517.

Терзић, Богдан. „Савременици о Кошутићу као русисти“. [У:] Р. Маројевић (ур.) Славистички зборник 1: Радован Кошутић и развој југословенске славистике. Београд: Савез славистичких друштава СР Србије, 1986, 21-30.

Терзић, Богдан. „Културолошки аспект Кошутићевих Писама из Петрограда (поводом 140-годишњице рођења Р. Кошутића)“. Славистика X, 2006: 25-31. 


\title{
Драгана Радойчич
}

\section{РУСИСТИЧЕСКОЕ НАСЛЕДИЕ РАДОВАНА КОШУТИЧА В НАУЧНОЙ КРИТИКЕ}

\begin{abstract}
Резюме
В статье говорится о вкладе Радована Кошутича в сербскую филологию и лингвистику. Кошутич по праву считается основоположником сопоставительного изучения русского и сербского языков и творцом дифференциального метода в изучении и преподавании русского языка, как инославянского в нашей языковой среде, что считается фундаментом сербской русистики. Данная статья представляет собой попытку короткого обзора работ и статей о Радоване Кошутиче, а также мнений и отзывов югославских и сербских русистов о его трудах.

Ключевые слова: Радован Кошутич, грамматика, дифференциальный метод, методология изучения инославянского языка, лингводидактика, конфронтативный анализ.
\end{abstract}

